\title{
Learning in 4.0 Era: Transformation of E-Learning to Strengthen Digital Literacy of Students' Primary Teacher Education Study Program
}

\author{
Ilham Syahrul Jiwandono* \\ Primary School Teacher Education \\ Study Program \\ University of Mataram \\ Mataram, Indonesia \\ ilham_jiwandono@unram.ac.id
}

\author{
K Khairunnisa \\ Primary School Teacher Education \\ Study Program \\ University of Mataram \\ Mataram, Indonesia \\ khairunnisapgsd2@gmail.com
}

\author{
Itsna Oktaviyanti \\ Primary School Teacher Education \\ Study Program \\ University of Mataram \\ Mataram, Indonesia \\ itsna@unram.ac.id
}

\author{
N Nurwahidah \\ Primary School Teacher Education Study Program \\ University of Mataram \\ Mataram, Indonesia \\ nurwahidah@unram.ac.id
}

\author{
Ketut Sri Kusuma Wardani \\ Primary School Teacher Education Study Program \\ University of Mataram \\ Mataram, Indonesia \\ srikusumawardani@unram.ac.id
}

\begin{abstract}
Learning 4.0 requires all parties to continue to innovate following developments in technology, information, and communication. One of the problems today is that lecturers use more conventional learning models (face to face) which make students bored and uninterested in participating in the learning process. This causes the results expected by the lecturers are not to follow reality. To overcome this problem, innovation is needed, namely using e-learning. The purpose of this study is to assist students in strengthening their knowledge of using digital technology in the learning process so that the expected results are by what is designed. The research approach used a descriptive qualitative approach. Research location in primary teacher education study program, University of Mataram. Data collection techniques using interviews, documentation, and observation. The primary data sources were 37 students and 3 lecturers, while the secondary data sources were observations and documentation on the learning process in the classroom. Data analysis techniques through data condensation, data presentation, and concluding. The results showed: 1) There was an increase in student skills in using technology in the learning process. 2) Increasing student knowledge about applications that can be used for the learning process. 3) The growing awareness of students on the use of gadgets in the learning process. After this research is carried out, teachers must be able to innovate in the learning process so that students can recognize and implement various types of learning applications.
\end{abstract}

Keywords — Learning 4.0, e-learning, digital literacy

\section{INTRODUCTION}

The demands for education in the 21st century are getting heavier. Education is becoming increasingly important to ensure that educators and students can use technology and information media and can work and survive using life skills. There are three 21 st century educational skills, namely: (1) life and career skills, (2) learning and innovation skills, and (3) information media and technology skills. These three skills are summarized in a scheme called 21 st-century knowledge [1]. Technological development very rapidly encourages various educational institutions to take advantage of the system e-learning to increase the effectiveness and flexibility of learning. Through e-learning, materials can be accessed anytime and from anywhere. The problem that arises at this time is that the learning process that is often encountered in class is learning face to face which makes some students feel bored to follow it [2].

The emergence of learning in the form of e-learning in the learning process is the answer to overcoming the problems above. According to Castle and McGuire in Syarif [3], $e$ learning can improve the learning experience because students can learn anywhere and in any condition as long as they are connected to the internet without having to take faceto-face learning.

The use of e-learning in the 4.0 era has a major contribution to educational institutions, including the achievement of distance learning goals [4]. Various media can also be used to support the implementation of online learning. For example, virtual classes use Google Classroom, Edmodo, and Schoology services [5], and instant messaging applications such as WhatsApp [6]. Online learning can even be done through social media such as Facebook and Instagram [7]. Online learning connects students with learning resources (databases experts/instructors, libraries) that are physically separated or even far apart but can communicate with each other, interact or collaborate (directly / synchronously and indirectly / asynchronously). E-learning is a form of distance learning that utilizes telecommunications and information technologies, such as the Internet, CD-ROOM [8]. This study aims to determine the description e-learning process.

\section{METHODS}

The method used in this research is a qualitative method, with a descriptive research approach in which data is collected and expressed in the form of words and pictures, words are 
arranged in sentences, for example, sentences from interviews between researchers and informants. In this study, the researcher will clearly describe the implementation of $e$ learning. Based on how to get the data, this research is included in the type of field research (field research) because the researcher is directly involved with the object of research and deepens the problems that occur in the research location. This research was conducted from April to November 2020 (8 months). The place of research is in the primary teacher education Study Program of the University of Mataram. The primary data source to answer the research objectives was interviews with human resources which has 49 lecturers. The number of lecturers taken as respondents was 3 lecturers and 37 students from the students. This study uses data collection techniques using interviews and documentation. Data analysis using data condensation, data presentation, and concluding.

\section{RESULT AND DISCUSSION}

\section{A. 4.0 Learning process}

At this time, the world is faced with a phenomenon related to health problems, namely the coronavirus or Covid-19, many countries are affected by this virus, Indonesia is one of them. As of January $15,2021,882,418$ positive cases have been detected in Indonesia. For this reason, the government took a policy by implementing social distancing to minimize the transmission of Covid-19. Social distancing itself is an activity in which everyone is required not to be close to one another. By avoiding all kinds of gatherings or gatherings to prevent Covid-19 transmission. Therefore, all activities such as teaching and learning activities (KBM) at schools and universities must be carried out at home or carried out online to prevent the spread of Covid-19.

Starting in the odd semester of 2020/2021, the primary teacher education Study Program of the University of Mataram implements learning 4.0 in full. Learning 4.0 is learning that integrates information technology in the learning process. The era of the industrial revolution 4.0 is a tough challenge for Indonesian teachers. Quoting Jack Ma at the annual meeting World Economic Forum 2018, education is the great challenge of this century. If we do not change the way we educate and learn and teach, in the next 30 years we will have great difficulties.

Learning 4.0 is learning that uses an internet network with accessibility, connectivity, flexibility, and the ability to bring up various types of learning interactions. Research conducted by Jiwandono [9] shows that the use of the internet and multimedia technology can change the way of conveying knowledge and can be an alternative to learning carried out in traditional classrooms. Online learning is learning that can bring together students and lecturers to carry out learning interactions with the help of the internet [10]. At the implementation level, online learning requires the support of mobile devices such as smartphones or android phones, laptops, computers, tablets, and iPhones which can be used to access information anytime and anywhere [11]. Higher education institutions during the WFH period need to carry out strengthening of online learning [12].

Education and learning that are loaded with knowledge, overriding the content of attitudes and skills as currently implemented, will result in students who are unable to compete with machines. The dominance of knowledge in education and learning must be changed so that later Indonesian young people can outperform machine intelligence while being able to be wise in using machines for their benefit. The results of an interview with $\mathrm{S}$, one of the students obtained the results:

"The learning is very maximal in my opinion because, in the current pandemic, learning that requires technology plays a very important role, where the lecture system can be carried out remotely with the help of technology. implemented face-to-face even through online".

On the other hand, YH said that learning 4.0 was quite good, following excerpts from the interview:

"It's good. Because the study program has been able to adjust to the current situation. Learning is carried out using the zoom application, google meet, and various applications that can help with these online lectures. The implementation is good enough to use technology, but it is still lacking in overcoming the existing problems if at any time there are obstacles".

The above opinion was also reinforced by the WH who said:

"Thank God, information technologybased learning in the lecture process at the Study Program went well, despite the Coronavirus outbreak".

Another resource person (RMS) said that:

"Learning 4.0 in study program can be implemented well, the proof is that by implementing this learning system students become more effective and efficient in obtaining learning materials. The implementation of information technologybased learning has been running well, when implementing it, it has run smoothly because you already understand how to use it. And not too difficult for students ".

The various opinions above are also supported by the results of interviews with various lecturers. The majority of lecturers have used LMS that supports the online learning process. The results of observations also show that some lecturers have also used LMS in the learning process. The following are the results of the documentation:

Some of the applications used for online learning include Zoom, Google Meet, BBB, and Whatsapp. Sources said:

"The learning has been running smoothly, using various applications that support the learning process such as Zoom, Google Meet, etc.".

The resource person $\mathrm{S}$ continued, that the zoom application is better than other applications in terms of carrying out communication. This is following the results of research [13] which state that the Zoom Meeting application is better 
because in the Zoom Meeting application communication between individuals is carried out orally compared to the use of learning applications that carry out written communication activities according to educational communication theory. . On the other hand, the RMS resource person said that google classroom is a very good application to use. This is following the results of research [14] which state that learning using google classroom media as a whole is quite effective with a tendency level of $77.27 \%$. The results of research on the use of Google classroom media were also carried out by Sari in 2019, where the results of her research revealed that the effectiveness of learning was influenced by the ease, usefulness, and quality of Google Classroom services. The following is the documentation of researchers using the Google Classroom application in the lecture process:

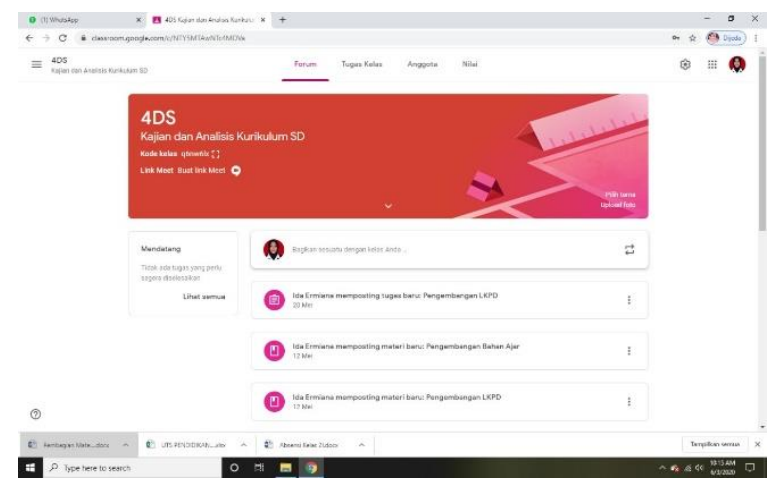

Fig. 1. The lecture process using the Google Classroom application.

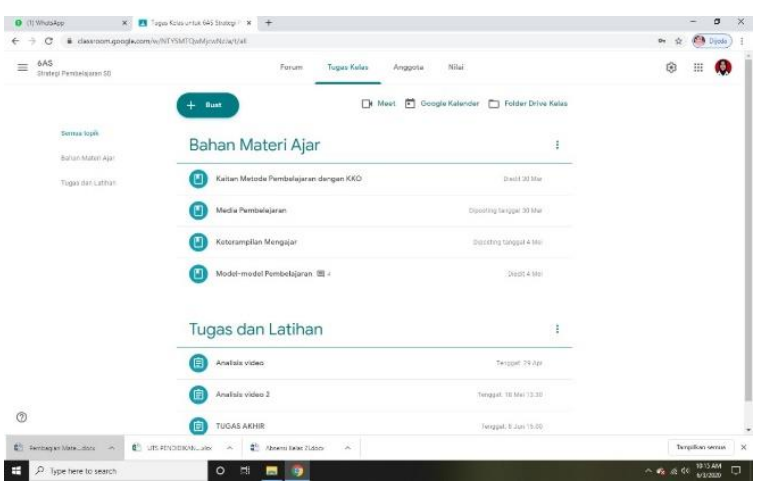

Fig. 2. Features in the Google Classroom application

Apart from using Google Classroom, some lecturers use the Big Blue Button (BBB) application in the learning process. Here's the documentation:

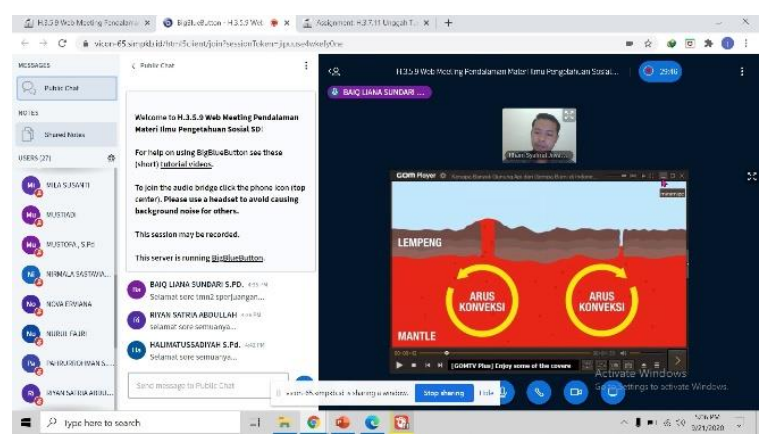

Fig. 3. The learning process using the BBB application

Online learning is an educational innovation to answer the challenges of the availability of varied learning resources. The success of a model or learning media depends on the characteristics of the students. The advantages of doing online learning, one of which is increasing the level of interaction between students and lecturers/teachers, learning can be done anywhere and anytime (time and place flexibility), Reaching students in a broad scope (potential to reach a global audience ), and make it easier to enhance and store learning materials (easy updating of content as well as archivable capabilities).

\section{B. Challenges in the 4.0 learning process}

Not all students can enjoy information and communication technology services easily and cheaply to carry out online learning. In several areas, especially in Java Island and most big cities, communication access can be obtained and is easily available. The gap in communication facilities between big cities, especially in Java and outside Java, has been going on for a long time. Compared to other provinces on the island of Java, the province of West Nusa Tenggara has its uniqueness. The province of West Nusa Tenggara is divided into two large islands, the islands of Lombok and Sumbawa. The province has 10 regencies/cities spread across the two islands. Its geographic condition is also different from the provinces in Java Island, which causes less even distribution of infrastructure development and information technology services in West Nusa Tenggara Province. Within West Nusa Tenggara Province itself, the infrastructure conditions are also different, for example in Mataram City and East Lombok Regency. Of course, this also affects students when online learning is carried out. To support civic education to run well, a breakthrough is needed in the form of changes in learning strategies and the tools/media used in delivering these subjects. The changes that exist are also intended to increase innovations that can make learning more effective and quality [15]. Covid-19 has had a positive impact in developing online learning which has been rarely done so far.

But the problem is, in NTB not all cellular communication providers have operated and have signals in all regions [16]. Ownership of ICT equipment in West Nusa Tenggara, which consists of radio, television, mobile phone, computer, and internet access, is generally low. When compared with the ownership of ICT equipment nationally, the ownership of ICT in NTB is below the average [16]. There are 37 students of primary school teacher education study program class $2 \mathrm{H}$ who take Pkn SD education courses and are spread across 10 cities/districts, except for North Lombok district plus one 
student from Alor, NTT. The following are the results of the author's documentation:

TABLE I. DISTRIBUTION OF STUDENT DOMICILES

\begin{tabular}{lll} 
No & Domicilies & Number of Students \\
\hline 1 & North Lombok District & 0 \\
\hline 2 & Central Lombok District & 9 \\
\hline 3 & East Lombok District & 8 \\
\hline 4 & West Lombok Dictrict & 4 \\
\hline 5 & Sumbawa District & 1 \\
\hline 6 & West Sumbawa District & 2 \\
\hline 7 & Dompu District & 1 \\
\hline 8 & Bima District & 2 \\
\hline 10 & Bima City & 2 \\
\hline 11 & Mataram City & 7 \\
\hline Total & & 1 \\
\hline
\end{tabular}

From the data above, information is obtained that students from Central Lombok dominate with 9 students, followed by East Lombok Regency with 8 students, Mataram City with 7 students, West Lombok Regency 4 students, West Sumbawa regency, Bima regency, and the city bima every 2 students and finally Sumbawa district, Dompu, and Alor (NTT) districts 1 student each. While the providers used by students are as follows:

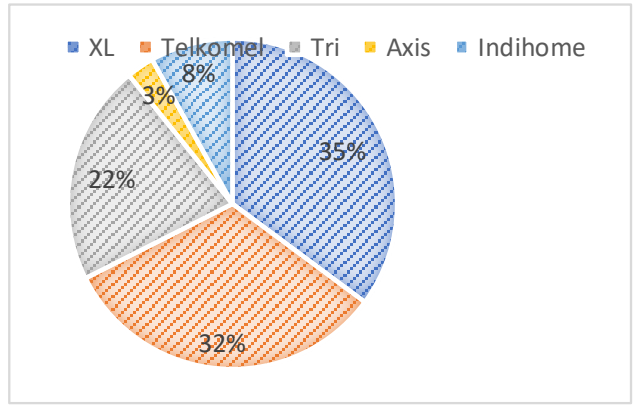

Fig. 4. Providers used by students.

From the data above, information is obtained that most students use XL providers with 13 students (35\%), then Telkomsel 12 students (32\%), followed by Tri 8 students (22\%), Indohome 3 students (8\%), and finally Axis 1 students (3\%). Meanwhile, the expenses incurred to buy credit/internet packages are as follows:

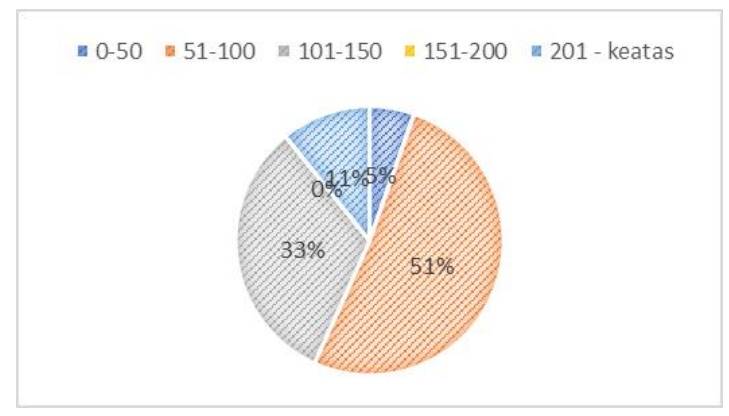

Fig. 5. Total costs incurred by students in buying pulses/data
From the data above, it is obtained information that the total costs incurred by students. Students who spend 0-50 thousand are 2 students (5\%), 51-100 thousand 19 students (51\%), 101-150 thousand 12 students (33\%), 151-200 thousand 0 students $(0 \%)$ and above. 200 thousand 4 students $(11 \%)$. The results of interviews with students obtained information that the state has the potential to increase with the existence of online learning. This is certainly burdensome for the finances of students who on average still rely on pocket money from their parents. From the results of interviews with each student, there are several difficulties for students in online learning:

Pertama, kurangnya sinyal. Narasumber menjelaskan dia harus pindah ke desa sebelah yang First, lack of signals. The resource person explained that he had to move to the next village with a good internet connection to send the assignment given by the lecturer. The documentation results also show this, when learning is carried out using the Zoom platform, many students have difficulty entering because of the difficulty of the internet signal, here are the results of the author's documentation:

Second, frequent blackouts. Many students also complain about this, especially students who live far from cities. Frequent blackouts hinder lectures. This can have a big impact because laptops or cellphones also need electricity to operate them. Many students are late in submitting assignments because their laptop or cellphone batteries have died due to their exhausted power. The blackout also resulted in the loss of the signal which obviously would hinder student work.

Third, tight task deadlines. The students also complained about the number of tasks done by students and tight deadlines. One of the speakers explained that in one day on average there are two to three courses which the time of collection is concurrent. This of course becomes a burden for students which leads to decreased health. The resource person explained that he had stomach ulcers due to late eating as a result of doing the continuous assignments given by the lecturer.

Fourth, decreased health. It cannot be denied that constantly staring at the screen of a laptop or cellphone can cause headaches, red eyes, and a career. This was experienced by one of the students. Often and for the length of time someone works with a computer, it can cause serious eye complaints. Complaints often expressed by computer workers are eye fatigue which is an early symptom, dry eyes, burning eyes, blurred vision, double vision, headaches, pain in the neck, shoulders, and back muscles. If this happens it is feared that it will interfere with the immunity of students which has the potential to become weak.

Fifth, the type of platform used. Each lecturer has a different way of teaching online. There are dsoen using Google Clasroom, Moodle, Webex, Zoom, Whatsapp, Email. This certainly affects students who must master all platforms. For students whose daily activities are with technology, this should not be an obstacle. What if there are students who are stuttering about technology? This is of course a big obstacle. However, online learning must still be implemented because it is the most sensible way to do learning. By doing online learning, many benefits are felt by students, especially those who are not familiar with the technology. 
Sixth, do not understand the material provided by the lecturer. Compared with face to face. Mastery of student material also received attention. If in a face-to-face lecture the lecturer explains the material easily, it is different from online learning. Many lecturers only give assignments without providing material so that students' knowledge about subjects needs to be questioned again.

Seventh, inconsistent. Many lecturers give assignments not according to their class schedule. For example, the course schedule is Monday, the lecturer gives assignments on Tuesday. Even though on Tuesday other courses must be taken by students. This makes assignments pile up which can cause students to become stressed. Eighth, the loss of time with family. Time with family is getting limited because almost every day students are dealing with laptops.

\section{CONCLUSION}

E-learning uses the internet network in its implementation. Online learning is divided into three categories, namely: Adjunct, blended, and fully. Meanwhile, what is discussed in this study is the category fully, where learning uses the internet in full. The e-learning has been going well. Almost all students and lecturers can participate in the learning process. Various obstacles faced by students in e-learning include: lack of signals, frequent power cuts, tight deadlines task, decreased health, many platforms used, not understanding learning materials, inconsistent lecturers, loss of time with family. Elearning has been proven to help students improve their skills in using learning applications, for example, students know how to share screens, download articles in journals, etc. Even though they do not carry out the learning process directly, the lecturer should not directly give assignments, but explain the material first. Because the student domicile spreads throughout the province of West Nusa Tenggara, the lecturer should understand that not all student areas get a good internet signal like in Mataram city. In giving assignments, the lecturer should pay attention to the duration of the collection time because there are also many student assignments in other courses.

\section{ACKNOWLEDGMENT}

Thanks to the Faculty of Teacher Training and Education, University of Mataram for supporting this research so that it runs well. Material or non-material support is very helpful for the research team in carrying out its duties in the field. Thanks are also due to the Primary Teacher Education Study Program of the University of Mataram for providing a place to research so that it runs smoothly.

\section{REFERENCES}

[1] Trilling, Bernie and Fadel, C. (2009). 21st Century Skills: Learning for Life in Our Times.

[2] Hunaiyan, Ahmed, et al. (2009). The Design Of Multimedia Blended e-Learning System: Cultural Consideraion. IEEE.

[3] Syarif, I. (2012). Pengaruh Model Blended Learning Terhadap Motivasi Dan Prestasi Belajar Siswa SMK. Jurnal Pendidikan Vokasi, 234-249.

[4] Korucu, A. T., \& Alkan, A. (2011). Differences between m-learning (mobile learning) and elearning, basic terminology and usage of mlearning in education. Procedia - Social and Behavioral Sciences. https://doi.org/https://doi.org/10.1016/j. sbspro.2011.04.029

[5] Enriquez, M. A. S. (2014). Students Perceptions on the Effectiveness of the Use of Edmodo as a Supplementary Tool for Learning. DLSU Research Congress. https://doi.org/https://doi.org/10.1017/CBO9781107415324.004.

[5] Iftakhar, S. (2016). Google Classroom: What Works And How? Journal of Education and Social Sciences.

[5] Sicat, A. S. (2015). Enhancing College Students' Proficiency in Business Writing Via Schoology. International Journal of Education and Research.

[6] So, S. (2016). Mobile instant messaging support for teaching and learning in higher education. Internet and Higher Education. https://doi.org/https://doi.org/10.1016Zj.iheduc.2016.06.001.

[7] Kumar, V., \& Nanda, P. (n.d.). Social Media in Higher Education. International Journal of Information and Communication Technology Education, 2018.

[8] Molinda, M. (2005). Instructional Technology and Media for Learning https://doi.org/https://doi.org/10.4018/ijicte.2019010107.

[9] Jiwandono, I. S. (2020). Analisis Metode Pembelajaran Komunikatif Untuk Ppkn Jenjang Sekolah Dasar. Elementary School Education Journal), 4(1), 9-19.

[10] Jiwandono, I. S., Setiawan, H., Oktaviyanti, I., \& Mataram, U. (2020). Persepsi Mahasiswa Terhadap Politisasi Corona Virus Disease (Covid-19) Korespondensi : 4(62), 286-299.

[11] Jiwandono, I. S., Nurhasanah, Husniati, Rosyidah, A. N. K., Anar, A. P., \& Maulyda, M. A. (2020). Mengatasi Problematika COVID-19 di Kalangan Mahasiswa: Webinar Peningkatan Pengetahuan Mahasiswa terkait Kebersihan Diri. Jurnal Pendidikan dan Pengabdian Masyarakat, 3(3).

[12] Silvana, H., \& Darmawan, C. (2018). Pendidikan Literasi Digital Di Kalangan Usia Muda Di Kota Bandung. Pedagogia, 16(2), 146. https://doi.org/10.17509/pdgia.v16i2.11327

[13] Haqien, D., Rahman, A. A., \& Sejarah, P. (2020). Pemanfaatan Zoom Meeting Untuk Proses Pembelajaran Pada Masa Pandemi Covid-19. SAP (Susunan Artikel Pendidikan), 5(1).

[14] Sabran, \& Sabara, E. (2019). Keefektifan Google Classroom sebagai media pembelajaran. Prosiding Seminar Nasional Lembaga Penelitian Universitas Negeri Makasar, 122-125. https://webcache.googleusercontent.com/search?q=cache:SS jKM_r 2TAJ:https://ojs.unm.ac.id/semnaslemlit/article/download/8256/476 $7+\& \mathrm{~cd}=2 \& \mathrm{hl}=\mathrm{id} \& \mathrm{ct}=\mathrm{clnk} \& \mathrm{gl}=\mathrm{id}$

[15] Ikawati, H. D. (2019). Pengembangan Media Video Permainan Tradisional Suku Sasak Untuk Pelestarian Budaya Dan Sumber Belajar Muatan Lokal. Jurnal Teknologi Pendidikan, 20(3), 234-248.

[16] Wahyudiyono. (2016). Penggunaan Teknologi Informasi Dan Komunikasi Di Nusa Tenggara Barat. Jurnal Komunika: Jurnal Komunikasi, Media dan Informatika, 5(1), 29. https://doi.org/10.31504/komunika.v5i1.636 